Article

\title{
Fucoidan Extracted from Undaria pinnatifida: Source for Nutraceuticals/Functional Foods
}

\author{
Yu Zhao ${ }^{1, *}$, Yizhou Zheng ${ }^{1}$, Jie Wang ${ }^{1}$, Shuyi Ma ${ }^{1}$, Yiming Yu ${ }^{1}$, William Lindsey White ${ }^{2}$, \\ Shiping Yang ${ }^{1}$, Fan Yang ${ }^{1,3}$ and Jun $\mathrm{Lu}^{1,2,4,5,6,7, * \mathbb{D}}$ \\ 1 Life and Environment Science College, Shanghai Normal University, 100 Guilin Road, Shanghai 200234, China; \\ 1000441512@smail.shnu.edu.cn (Y.Z.); granger2013@163.com (J.W.); 1000441341@smail.shnu.edu.cn (S.M.); \\ 1000441506@smail.shnu.edu.cn (Y.Y.); shipingy@shnu.edu.cn (S.Y.); bayer@shnu.edu.cn (F.Y.) \\ 2 School of Science, Faculty of Health and Environmental Sciences, Auckland University of Technology, \\ Auckland 1010, New Zealand; lindsey.white@aut.ac.nz \\ 3 State Key Laboratory of Bioreactor Engineering, East China University of Science and Technology, \\ 130 Meilong Road, Shanghai 200237, China \\ 4 School of Interprofessional Health Studies, Faculty of Health and Environmental Sciences, \\ Auckland University of Technology, Auckland 1010, New Zealand \\ 5 Institute for Biomedical Technology, Auckland University of Technology, Auckland 1010, New Zealand \\ 6 College of Life and Marine Sciences, Shenzhen University, Shenzhen 518060, China \\ 7 College of Food Engineering and Nutrition Sciences, Shaanxi Normal University, Xi'an 710119, China \\ * Correspondence: zhaoyu@shnu.edu.cn (Y.Z.); jun.lu@aut.ac.nz (J.L.); \\ Tel.: +86-21-6432-1033 (Y.Z.); +64-9-9219999 (ext. 7381) (J.L.); Fax: +86-21-6432-2933 (Y.Z.); +64-9-9219175 (J.L.)
}

Received: 31 July 2018; Accepted: 8 September 2018; Published: 9 September 2018

\begin{abstract}
The importance of fucoidan as a functional ingredient in food, health products, and pharmaceutics is well-recognized due to its beneficial biological effects. Fucoidan is usually extracted from brown seaweeds, including Undaria pinnatifida. Fucoidan exhibits beneficial bio-activity and has antioxidant, anticancer, and anticoagulant properties. This review focuses on the biological activity of $U$. pinnatifida-derived fucoidan and investigates its structure-activity or fraction-activity relationship. It also describes several fucoidan extracts, along with their claimed anticancer effects. It aims to provide information and thoughts for future research such as the development of fucoidan into functional foods or nutraceuticals.
\end{abstract}

Keywords: fucoidan; chemical composition; molecular weight; locations; fucose; sulphate; nutraceutical

\section{Introduction}

Many studies have focused on marine products, including seaweeds, in the pursuit of novel drugs discovery/development [1]. Fucoidan extracted from Undaria pinnatifida is one of these, as it has proven its bioactivity, including anticancer, antioxidant, antiviral, and anticoagulant activities. Fucoidan has garnered increased research interest in both pharmaceutical and functional food industries in recent years (Figure 1).

Fucoidan is a natural sulfated polysaccharide that exists mainly in the cell wall matrix of various species of brown seaweed that are consumed by humans, such as mozuku, kombu, limumoui, bladderwrack, and wakame (the Japanese name of $U$. pinnatifida) [2,3]. It was first isolated by Kylin in 1913 [4], and since then, fucoidan from many different species of brown seaweed has been successfully isolated, each with slightly different structures and biochemical properties. The brown seaweeds containing fucoidan are widely consumed as part of the normal diet in East Asia, particularly in Japan, China, and Korea. Wakame blades are green when cooked and have a subtly sweet flavor and satiny texture. The blades are normally cut into small pieces as they tend to expand during cooking. 


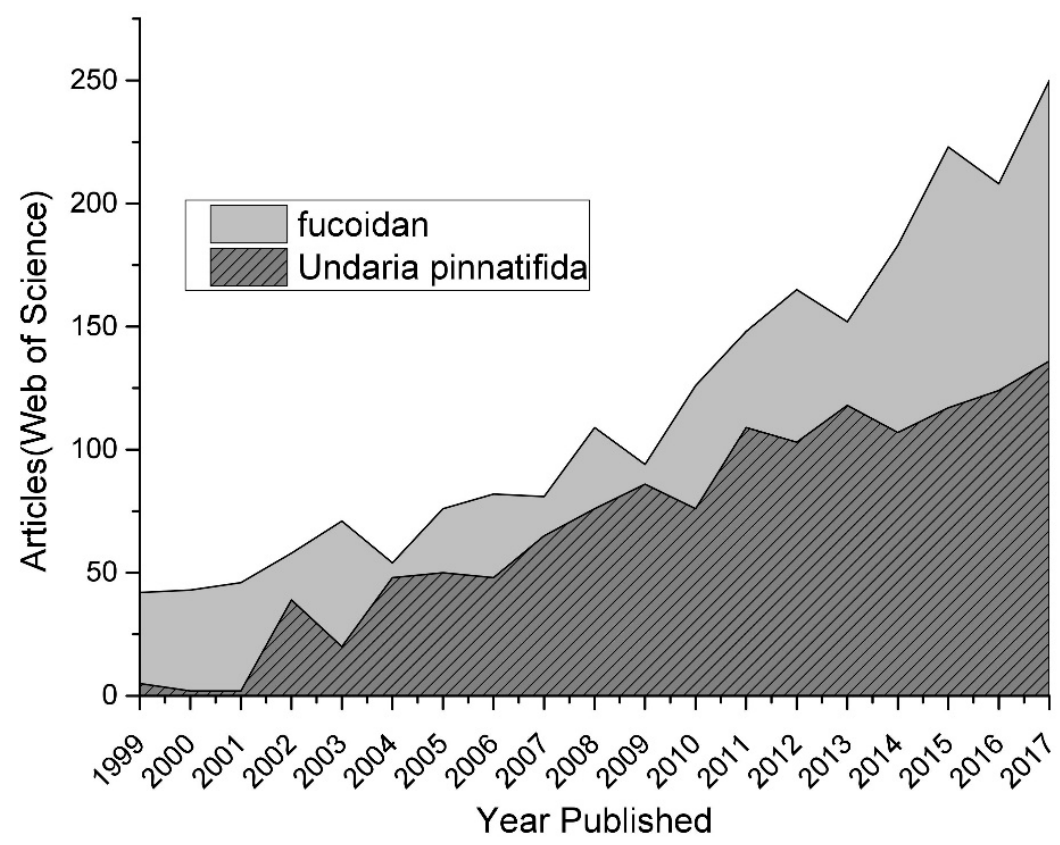

Figure 1. The trend of research on fucoidan as depicted by the number of published articles (Web of Science) in the last two decades. The number of articles was obtained according to topics being assigned in the ISI Web of Science search engine with the following topic search terms: Fucoidan; Undaria pinnatifida.

In Japan and Europe, wakame is consumed either dried or salted. It is mainly used in soups (particularly miso soup) and salads (tofu salad), or simply used as a side dish. These dishes are typically dressed with soy sauce and vinegar/rice vinegar. In addition, Goma wakame, also known as seaweed salad, is a popular side dish at American and European sushi restaurants. Literally translated, it means "sesame seaweed", as sesame seeds and oil are usually included in the recipe.

The brown seaweed species U. pinnatifida (Figure 2) is native to the cold temperate seas of China, Japan, and Korea, and has been introduced in many other places including the Europe Atlantic, French Mediterranean, Australia, and New Zealand (Figure 3). It is regarded as a highly invasive species with a high tolerance for light, temperature, and salinity [5,6]. It is also highly fertile with high growth rate and large reproductive output, releasing spores all year round [6,7]. It is farmed extensively in Japan, Korea, and Japan and as such, it is an abundant source from which fucoidan could be extracted and used.

Fucoidan is usually extracted from the sporophyll of $U$. pinnatifida (Figure 2) [8]. However, a key difference between fucoidan from $U$. pinnatifida and those from of other brown seaweed species such as Fucus vesiculosus lies in the composition of monosaccharides that form the backbone of the polysaccharide molecule [2,3]. Fucoidan from $U$. pinnatifida is sulfated galactofucan [4]. In contrast, fucoidan isolated from the vast majority of other brown seaweeds mainly consists of sulfated fucose [4]. Literature shows that sulfate content, monosaccharide composition, and structural conformation of fucoidan affect its biological activity [9-11]. As such, it is suggested that fucoidan from U. pinnatifida with different monosaccharide composition and structural conformation, would possess a wide range of biological activities, which offers itself as an attractive functional ingredient of health products $[2,3]$. 


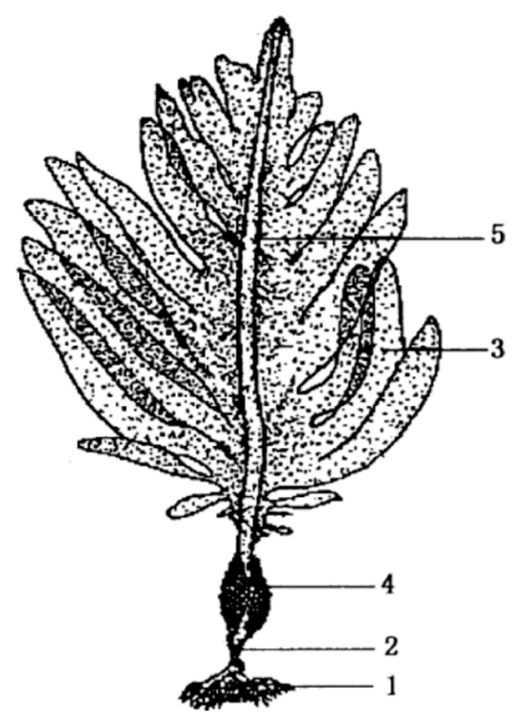

Figure 2. Parts of Undaria pinnatifida. 1 = Holdfast, 2 = Stipe, 3 = Blade, $4=$ Sporophyll, $5=$ Midrib.

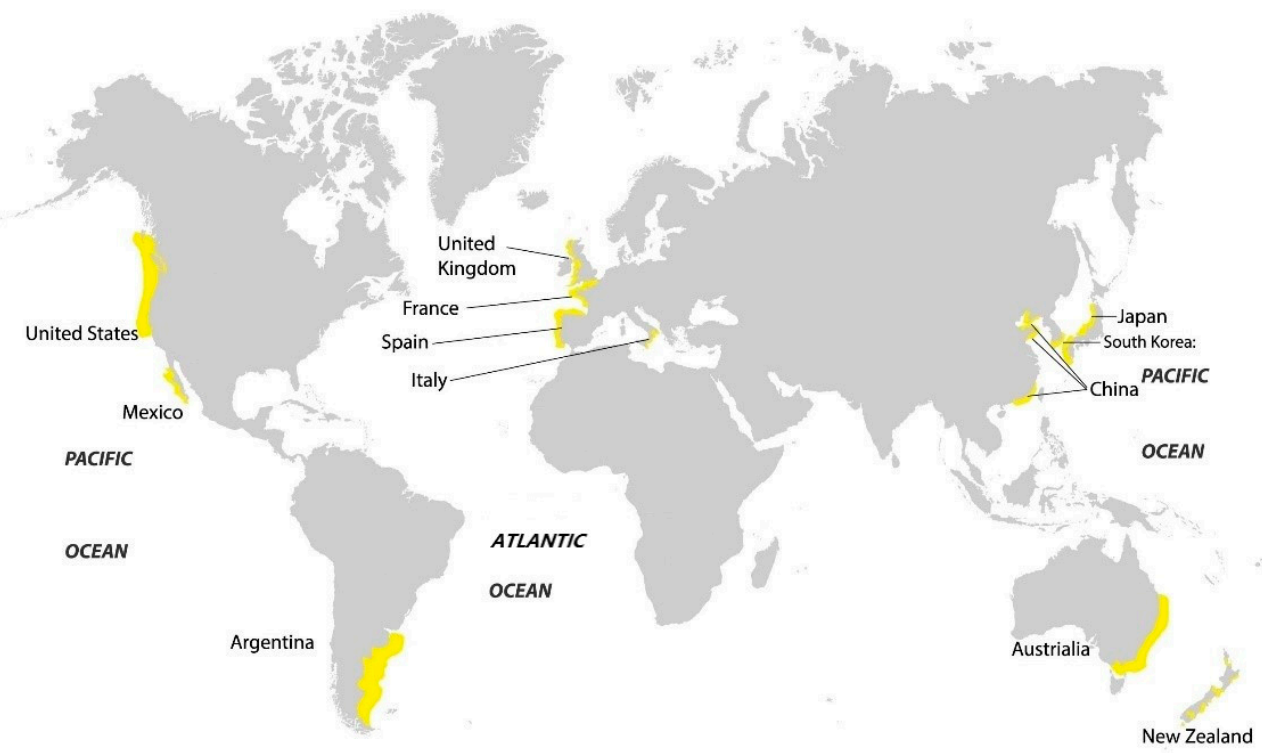

Figure 3. Distribution of Undaria pinnatifida around the world.

\section{The Extraction of Fucoidan from U. pinnatifida}

In 1913, for the first time, Kylin named the polysaccharide extracted from the brown seaweed palmate kelp as fucoidin [12] and it has now been uniformly named fucoidan or sulfated fucan. Fucoidan is a water-soluble polysaccharide. There are a number of commonly used methods to extract fucoidan, including water extraction, acid extraction, microwave-assisted extraction, ultrasonication extraction, and enzyme-assisted extraction [13]. There are reports that the yield of fucoidan varies with different extraction methods [14]. The extraction methods of fucoidan are briefly summarized in Table 1. 
Table 1. Extraction methods and their rationale, properties, and the yield in each best condition.

\begin{tabular}{|c|c|c|c|c|c|}
\hline Extraction Method & Rationale & Properties & Extraction Conditions & Yield & Reference \\
\hline Hot water extraction & $\begin{array}{l}\text { A method based on the solubility } \\
\text { of fucoidan in hot water and the } \\
\text { insolubility in ethanol and other } \\
\text { organic solvents. }\end{array}$ & $\begin{array}{l}\text { Low cost, simple operation, } \\
\text { but time-consuming and using } \\
\text { a large amount of solvent. }\end{array}$ & $\begin{array}{l}\text { U. pinnatifida was washed by ethanol at } \\
80^{\circ} \mathrm{C} \text { for } 1 \mathrm{~h} \text {, then was extracted in } \\
\text { 60-time weight of water for } 7 \mathrm{~h} \text { at } 100^{\circ} \mathrm{C} \text {. } \\
\text { Supernatant was precipitated } \\
\text { with ethanol. }\end{array}$ & $12.9 \%$ & Jia et al. [15] \\
\hline Dilute acid extraction & $\begin{array}{l}\text { Based on the solubility of } \\
\text { fucoidan in dilute hydrochloric } \\
\text { acid aqueous solution. It is } \\
\text { difficult for fucoidan to dissolve } \\
\text { at lower pH value but easy for } \\
\text { part of its sodium salt. }\end{array}$ & $\begin{array}{l}\text { The extraction rate is not high, } \\
\text { and the structure of fucoidan is } \\
\text { easy to be destroyed which } \\
\text { affects the bioactivity. }\end{array}$ & $\begin{array}{l}250 \mathrm{~g} \text { dried sporophyll was added to } 4 \mathrm{~L} \\
\text { of } 0.1 \mathrm{~N} \mathrm{HCl} \text { for } 24 \mathrm{~h} \text { at ambient } \\
\text { temperature. The extract was filtered, } \\
\text { and the filtrate was neutralized with } 1 \mathrm{~N} \\
\mathrm{NaOH} \text {. Fucoidan was precipitated with } \\
\text { 3:1 volume of } 75 \% \text { ethanol. }\end{array}$ & $3.9 \%$ & Kim et al. [16] \\
\hline $\begin{array}{c}\text { Microwave-assisted } \\
\text { extraction }\end{array}$ & $\begin{array}{l}\text { Microwave radiation penetration } \\
\text { has high energy, which can } \\
\text { shortening extraction time to } \\
\text { improve efficiency and reduces } \\
\text { the use of organic solvent. }\end{array}$ & $\begin{array}{c}\text { Fucoidan is extracted more } \\
\text { selectively and quicker with } \\
\text { better yields, using less energy } \\
\text { and solvent, reducing costs and } \\
\text { waste, and less destructive to } \\
\text { the structure }\end{array}$ & $\begin{array}{l}1 \mathrm{~g} \text { milled dry seaweed was suspended } \\
\text { in } 25 \mathrm{~mL} \text { of distilled water and placed } \\
\text { into the extraction vessel. The } \\
\text { suspensions were irradiated under } \\
120 \text { psi pressure for } 1 \mathrm{~min} \text {. }\end{array}$ & $18.2 \%$ & Rodriguez-Jasso et al. [17] \\
\hline $\begin{array}{l}\text { Ultra-sonication } \\
\text { extraction }\end{array}$ & $\begin{array}{l}\text { Ultrasonication produces } \\
\text { cavitation, directs dynamic shock } \\
\text { waves on the surface of materials. } \\
\text { It breaks the cell wall of organic } \\
\text { materials and facilitate the } \\
\text { extraction of fucoidan. }\end{array}$ & $\begin{array}{l}\text { Higher extraction yields } \\
\text { and lower damage to } \\
\text { fucoidan structure }\end{array}$ & $\begin{array}{l}10 \text { g powdered materials were added to } \\
0.1 \mathrm{~N} \mathrm{HCl}(\mathrm{PH}=2) \text { and treated by } \\
\text { ultrasonication at room temperature, } 80 \% \\
\text { amplitude for } 6 \mathrm{~h} \text {. The supernatant was } \\
\text { neutralized }(\mathrm{PH}=7) \text { with } 0.1 \mathrm{~N} \mathrm{NaOH} \text {. }\end{array}$ & $33.0 \pm 0.4 \%$ & Song et al. [18] \\
\hline $\begin{array}{l}\text { Ultra-filtration membrane } \\
\text { extraction }\end{array}$ & $\begin{array}{l}\text { It is the use of enzymes to disrupt } \\
\text { the structure of cell walls, } \\
\text { promote the dissolution of } \\
\text { fucoidan, and greatly shorten the } \\
\text { extraction time. }\end{array}$ & $\begin{array}{l}\text { Extract fucoidan effectively } \\
\text { while maintaining its structure } \\
\text { and biological activity }\end{array}$ & $\begin{array}{l}\text { Algae powder:water at } 1: 20 \text { ratio was } \\
\text { pressed at } 25^{\circ} \mathrm{C} \text { to become seaweed } \\
\text { slurry. Slurry at } \mathrm{PH}=6.0 \text { was added } 2.0 \% \\
\text { enzyme and reacted for } 2 \mathrm{~h} \text { at } 40{ }^{\circ} \mathrm{C} \text {, then } \\
\text { heated to } 80^{\circ} \mathrm{C} \text { rapidly and extracted for } \\
1 \mathrm{~h} \text {, centrifuged, dialyzed, precipitated } \\
\text { by ethanol, and finally dried. }\end{array}$ & $7.76 \%$ & Wang et al. [19] \\
\hline
\end{tabular}




\section{The Structure and Function of Fucoidan from U. pinnatifida}

In this part, the structure-activity relationship is described. Three clear biological activities: anticancer, antioxidant, and anticoagulant activity are described in detail. The fucoidan structure factors effecting anticancer activity are mainly the content of sulfate and the linking mode of the polysaccharide skeleton, and the main factors affecting the antioxidant and anticoagulant activity are the content of sulfate and the molecular weight of the polysaccharide.

\subsection{Fucoidan Basic Structure}

In 2006, researchers identified the monosaccharides that make up U. pinnatifida-derived fucoidan are fucose, xylose, galactose, glucose, rhamnose, and mannose [20]. The three most abundant monosaccharides are mannose, fucose, and galactose [21]. In addition to those basic monosaccharides, uronic acid, and sulfate are also present.

Neutral sugar analysis confirmed that fucose $(50.9 \% \mathrm{~mol})$ and galactose $(44.6 \% \mathrm{~mol})$ are the major neutral sugars of obtained polysaccharide, with small amounts of xylose and mannose. The ratio between fucose and galactose is approximately 1.1:1.0.

Using analytical methods, including HPLC, gel electrophoresis, elemental analysis, infrared, Raman, and mass spectrometry, it has been found that the connections between fucoidan monosaccharides are 1-3, 1-4, 1-6 glycosidic bonds [16,22]. The various saccharide bonds include 1-3 linked fucose, and 1-3, 1-4, and 1-6 linked galactose. The sulfate substitution sites are mainly at 2- or 4-positions of fucose residues, 3- or 6-positions of galactose residues [22,23]. There is still controversy about the composition and connection of fucose. One claim is that fucose and galactose in galactofucan may form separate blocks and intersperse in one polymer backbone [23]. Another is that there could be two separate polymers: fucan and galactofucan. From ESI-FTICR mass spectrometry analysis, it has been shown that galactose and fucose residues are successively linked to one polysaccharide molecule [23]. There are many kinds of fucoidans that varies with the type of algae extracted. Figure 4 lists the structure of fucoidans extracted from Fucales, Laminariales, and other brown seaweed.

The molecular size of fucoidan is also a significant part of the structural character. Sakai et al. (2003) reported that the molecular weight of fucoidan is $2000 \mathrm{kDa}$ [11]. Fucoidan isolated from the sporophylls of $U$. pinnatifida collected from Wando, South Korea, has an average molecular weight of $2100 \mathrm{kDa}$ [16]. The fucoidan from sporophylls of the same species harvested from a seaweed farm in the coastal area of Kijang, Yangshan County, South Korea, had an average molecular weight of $38 \mathrm{kDa}[24,25]$. Fucoidans with low molecular weights of 89, 35, 17, and $6 \mathrm{kDa}$ were obtained by radiation-degradation of a $378 \mathrm{kDa}$ fucoidan isolated from $U$. pinnatifida by Park and coworkers $[3,26]$. It is believed that the difference in molecular weight is caused by different extraction methods [24]. Many studies have shown that the molecular weight of the fucoidan is related to its biological activity.

Sulfate is a characteristic group of fucoidan structure. The content of sulfate is based on the elemental analysis (DS, moles of $\mathrm{SO}_{3}$ per mol of saccharide units),

$$
D S=\frac{\% \mathrm{~S}}{\% \mathrm{C}}(6+2 D A c) \frac{A_{\mathrm{C}}}{A_{\mathrm{S}}}
$$

where $\% \mathrm{~S}$ and $\% \mathrm{C}$ are the carbon and sulfur contents, $A_{\mathrm{C}}$ and $A_{\mathrm{S}}$ are the atomic weights of these elements, six and two are the amounts of carbon in the pyran ring and $O$-acetyl group, and $D A c$ is the degree of acetylation calculated by ${ }^{1} \mathrm{H}$ NMR. 


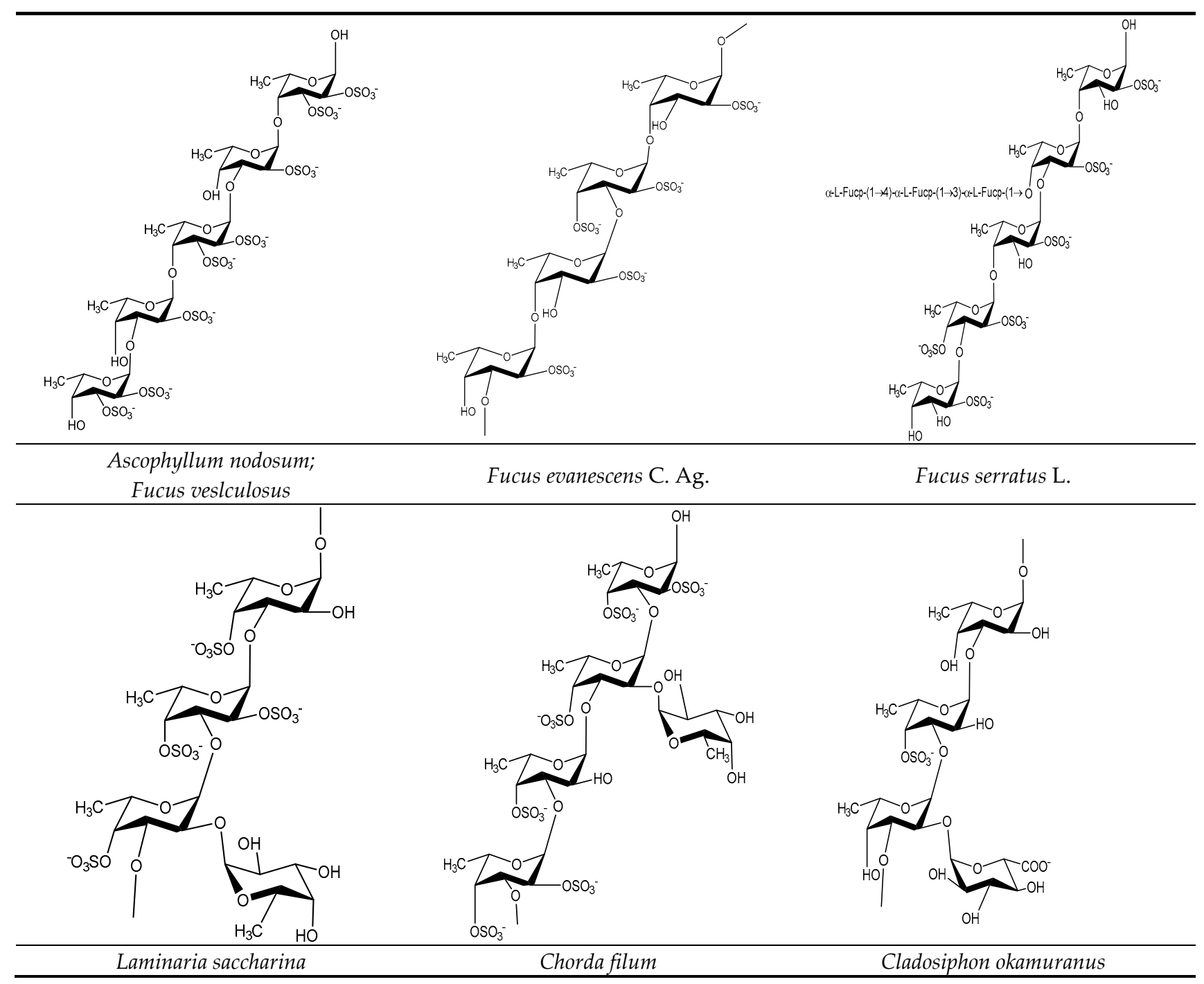

Figure 4. Taxonomic comparison of fucoidan or fucose-containing sulfated polysaccharides structures. 
The results of the elemental analysis show that no protein (non-nitrogen) was detected, while the sulfur content of $9.18 \%$ indicated a sulfated polysaccharide. The carbon content is relatively low, which is $23.03 \%$ [27]. Infrared spectrum analysis (IR) at $836 \mathrm{~cm}^{-1}$ and Raman spectrum analysis at $839 \mathrm{~cm}^{-1}$ indicate that the COS bond in the sulfate has bending vibration at the axial C-4 position $[28,29]$.

Igarashi et al. hydrolyzed the sporophyll of Japanese wakame, and the resulting infrared spectrum showed a band at $829 \mathrm{~cm}^{-1}$ and it was found that the bending vibration of $\mathrm{C}-\mathrm{O}-\mathrm{S}$ appeared at the $\mathrm{C}-2$ position [15]. There are two other studies show that the bending vibration of $\mathrm{C}-\mathrm{O}-\mathrm{S}$ is present at different carbon locations, thereby indicating that sulfate is a characteristic group of the structure of fucoidan $[12,14]$.

At the same time, it has been confirmed that the sulfate content effected the bioactivity of the fucoidan. Fucoidans extracted from different algae or different locations have different biological activities because it is a polymer mixture. The following Table 2 is a brief summary of the sulfate content detected in fucoidan grown in different countries:

Table 2. The mass fraction of fucoidan derived from $U$. pinnatifida grown in different countries.

\begin{tabular}{cccc}
\hline Region & Process & Mass Fraction & Ref. \\
\hline China & $\begin{array}{c}\text { Extracted and purified } \\
\text { polysaccharide from Wakame }\end{array}$ & $\begin{array}{l}43.20 \% \text { polysaccharide, 12.70\% sulfate, 9.78\% glucuronic acid } \\
\text { [2] }\end{array}$ \\
\hline South Korea & Purified fucoidan by HPLC & $52.34 \%$ neutral sugar, 26.2\% uronic acid, 7.4\% sulfate ester & [16] \\
\hline New Zealand & $\begin{array}{c}\text { U. pinnatifida was harvested from } \\
\text { Port Underwood, New Zealand }\end{array}$ & $\begin{array}{c}\text { Monosaccharide composition: fucose (39.24\%), xylose (28.85\%), } \\
\text { galactose (26.48\%), mannose (5.04\%), glucose }(0.95 \%) .\end{array}$ & $\begin{array}{c}\text { The minor components: sulfate }(15.02 \%), \text { uronic acid (1.24\%), } \\
\text { and protein }(0.36 \%) .\end{array}$ \\
\hline
\end{tabular}

In recent years, individual monosaccharide composition has been found to vary with season. The structural characteristics of individual monosaccharides vary with the collection time [31] and the age of the plant. From April to July in the Northern Hemisphere, fucoidan production increased five-fold. In addition, the monosaccharides constituting fucoidan are significantly affected by the season. The galactose content increases from April's 20.5\% to June/July's 38-39.5\%, and the content of mannose drops. The change in fucose content from April to July was not significant. The ratio of other monosaccharides also changed. The molar ratio of fucose to aspartic acid galactose changes from 1:0.34 to 1:0.66-0.69 [21]. Similar observations are reported by Honya et al. [32] and Fletcher et al. [33]. A New Zealand study also found that sulfate content in the extracted fucoidan increased more than twice within a 4-month period, while fucose content remains constant [34].

\subsection{Structure Characterization and Structure-Activity Relationship}

\subsubsection{Anticancer Properties of Fucoidan from U. pinnatifida}

A recent report shows that fucoidan isolated from the sporophyll of New Zealand U. pinnatifida exhibits similar cell growth-inhibition effects in breast adenocarcinoma cell line MCF-7, lung carcinoma cell line A-549, and colon adenocarcinoma cell line WiDr, in comparison with commercial fucoidan (from Sigma, St. Louis, MO, USA) isolated from F. vesiculosus [35]). Similar results are reported by another group where breast cancer cell line T-47D and melanoma cancer cell line SK-MEL-28 are susceptible to the anticancer effect of fucoidan isolated from U. pinnatifida grown in Japan Sea [2]. Park et al. showed that there was an enhanced inhibitory effect against melanin biosynthesis in B16BL6 melanoma cells with low molecular weight fucoidan [26]. It has also been shown that fucoidan from U. pinnatifida has antiproliferation effect on prostate and hepatocellular cancer cells. Research suggests that fucoidan treatment could induce intrinsic and extrinsic apoptosis pathways via the activation of extracellular signal-regulated kinase mitogen-activated protein kinase (ERK1/2 MAPK), the inactivation of p38 MAPK and phosphatidylinositol 3-kinase (PI3K)/Akt signaling pathways, and the downregulation of the Wnt/ $\beta$-catenin signaling pathway [36]. Further research 
suggested that fucoidan induces apoptosis via a ROS-mediated mitochondrial pathway. By increasing reactive oxygen species (ROS) production, fucoidan induces mitochondrial oxidative damage, mitochondrial membrane potential (MMP) depolarization, and release of cytochrome c; combined with downregulation of Livin and XIAP mRNA and activation of caspase-3 and caspase-9 [37]. Another report demonstrates that fucoidan can ameliorate hepatic infrared injury in mice via JAK2/STAT1-mediated apoptosis and autophagy [38].

The anticancer activity of fucoidan is influenced by its sulfate content; low molecular weight fucans isolated from Ascophyllum nodosum exhibited increased antiproliferative activity on fibroblast cell line CCL39 with increased sulfate content [33]. Likewise, oversulfated fucoidan from F. vesiculosus exhibited higher anti-angiogenesis potency on the growth of B16 melanoma cells, Lewis lung carcinoma, and Sarcoma 180 cell lines [34]. This suggests that the sulfate content of fucoidan may be critical in influencing its anticancer activity.

More interestingly, fucoidan isolated from $U$. pinnatifida exhibits stronger anticancer activity against breast cancer T-47D and melanoma SK-MEL-28 cell lines as compared to fucoidan isolated from Saccharina japonica. These fucoidans induced apoptosis in relevant cancer cell lines as well as they have antimetastatic activity blocking the interactions between cancer cells and the basement membrane. The authors attribute the higher anticancer activity to the types of glycosidic bonds that it possesses, where $U$. pinnatifida fucoidan has a backbone structure of $(1 \rightarrow 3):(1 \rightarrow 4)$-O-glycosidic bonds and S. japonica fucoidan has a backbone structure of $(1 \rightarrow 3)-O$-glycosidic bonds [2]. Fucoidan has also shown considerable anticancer potential against human liver cancer (HepG2) cells (LD 50, $18.01 \pm 1.2 \mu \mathrm{g} / \mathrm{mL}$ ). As such, it can be concluded that both sulfate content and types of glycosidic bonds play important role in determining the anticancer activity of fucoidan.

\subsubsection{Antioxidant Activities of Fucoidan from U. pinnatifida}

The antioxidant capacity of fucoidan isolated from various seaweed species has been demonstrated in the literature. It has been reported that fucoidan typically exhibits strong secondary antioxidant activity that is comparable to synthetic antioxidants such as butylated hydroxyanisole (BHA) and butylated hydroxytoluene (BHT) that are known for causing side effects in humans including cancer [31,39]. It has been reported that fucoidan isolated from Sargassum binderi exhibits significantly higher secondary antioxidant capacity, based on superoxide radical scavenging and hydrogen peroxide scavenging assays, than synthetic antioxidants BHA and BHT [38]. In another study, it was concluded that fucoidan isolated from Laminaria japonica exhibited significantly higher superoxide radical scavenging activities as compared to BHA, BHT, and $\alpha$-tocopherol [40]. This highlighted the potential of fucoidan as a source of antioxidant. Fucoidans extracted from U. pinnatifida from mussel farms in New Zealand, exhibit strong antioxidant activities using the DPPH scavenging and CUPRAC assays [34]. Another recent study prospects fucoidan from U. pinnatifida as a potential antioxidant that can effectively abrogate oxidative stress, too [41].

There have been numerous reports on the correlation between the antioxidant capacity of fucoidan and its sulfate content and molecular weight. In the same study conducted by Wang et al., it reports that the superoxide radical scavenging activity of the fucoidan sample enhances with increased sulfate content $[40,42]$. In a separate study, a similar trend has been observed where fucoidan extracted from F. vesiculosus and Padina gymnospora exhibit significantly higher antioxidant activity than fucan fractions with lower sulfate content [43-45].

Besides sulfate content, a correlation between molecular weight and the antioxidant capacity of fucoidan has also been reported in the literature [4]. One study compares the antioxidant capacity of five fucoidan fractions, with different molecular weight and sulfate content, isolated from L. japonica [46]. It shows that the high molecular weight fucoidan fractions show low inhibitory effects on low-density lipoprotein (LDL) oxidation while the low molecular weight fractions exhibited higher inhibitory effects [47]. It is also worth noting that all fractions contained different sulfate contents. Hence, this suggests that both sulfate content and molecular weight are important determinants of the antioxidant activity of fucoidan. 


\subsubsection{Anticoagulant Activity of Fucoidan from U. pinnatifida}

Previous studies have confirmed the anticoagulant and antithrombotic activity of fucoidan from the brown seaweeds Saccharina latissimi [48]. According to previous reports, the molecular weight of the fucoidan polymer is related to its anticoagulant activity [49]. One study found that the fucoidan polymer exhibited the strongest anticoagulant activity with the molecular weight from approximately $10 \mathrm{kDa}$ to $300 \mathrm{kDa}$ [9]. The activity of fucoidan extracted from U. pinnatifida on red blood cells has been studied by Caterina Faggio et al. Results show that fucoidans appeared to have no cytotoxic effect on the red blood cells, and the values of prothrombin time, activated partial thromboplastin time, and fibrinogen are significantly changed. The purified fucoidan significantly prolongs clotting time [50,51]. Various natural anticoagulants moderate the secondary hemostasis pathway and currently, heparin or low-molecular-weight heparin (LMWH) is frequently used clinically [52,53]. The current source of heparin is mainly from the animals, including from pig intestine or bovine lung. It is a commonly used natural medicine. The fucoidans interfere with both the extrinsic and intrinsic pathways of coagulation inhibiting clot formation, which has an action similar to that carried out by heparin. The development of anticoagulant drugs with fucoidans would be advantageous since their use would avoid the potential for contamination with prions or viruses in commercial heparins that are obtained from pig and bovine intestine. Moreover, with more specific activities or targets, fucoidans could find applications complementary to heparin. Therefore, new researches on discovering novel anticoagulants are still favored [54], and the above researches suggest that fucoidan from U. pinnatifida is a potential useful source of anticoagulant drug.

\subsubsection{Antibacterial Activity}

There have been a large number of reports on compounds derived from algae with antibacterial activity, such as acrylic acid, halogenated aliphatic compounds, terpenes, sulfur-containing heterocyclic compounds, and phenolic compounds $[55,56]$. However, few studies have been found in the literature regarding $U$. pinnatifida-derived fucoidan with antibacterial activity.

The antibacterial mechanism is due to a large amount of sulfuric acid and glucuronic acid in the depolymerization products of fucoidan, which have the property of polyanion. The depolymerized fucoidans bind to the bacterial membrane proteins and cause a membrane-disrupting effect that induces the expression of certain apoptotic factors, which leads to bacterial apoptosis. Antibacterial activity of fucoidan from $U$. pinnatifida has been tested and proven to be effective. The results show that the maximum zone of inhibition of the bacterial growth against $S$. aureus is $15.67 \pm 0.76 \mathrm{~mm}$. Compared with Gram-negative strains, Gram-positive bacterial strains are more inhibited by fucoidan. It may be due to the inhibition of peptidoglycan formation, or the presence of special cell wall components of Gram-negative bacteria that act as a barrier for fucoidan. The molecular mechanism of the activity needs to be further studied. Although, fucoidan has complex structure and the effective structure is not clear, the structural backbone has been elucidated by a recent study. The basic structure of fucoidan from $U$. pinnatifida is presented in Figure 5.

Based on these results, it can be concluded that fucoidan as a natural product can be used as a lead for the development of new drugs with various therapeutic potentials. Table 3 lists the biological functions of fucoidan extracted from $U$. pinnatifida. In addition to the above activities, fucoidan has other functions, such as anti-allergy. An experiment by Jiao and coworkers suggests that fucoidan might ameliorate allergic reactions [57].

The literature shows that the production of well characterized and reproducible fucoidan fractions on a commercial scale is possible. Thus, therapies from fucoidan could become a realizable goal [58]. Current status in fucoidan drug discovery, mechanisms of action and role of the well-defined structures has been summarized [59]. Accurate structure-function relationships have mostly been achieved when sulfated fucans and sulfated galactans of well-defined structures are used. These types of glycans become vital to identify the fucoidan chemical composition needed to achieve satisfactory clinical responses [59]. 
Table 3. Biological functions of $U$. pinnatifida.

\begin{tabular}{|c|c|c|c|c|}
\hline Function & Origin & Effective Molecule/Fraction & Mode of Action & Ref. \\
\hline Anti-lung carcinoma & Japan & Low molecular weight fucoidan fraction $(5-30 \mathrm{kDa})$ & Induce apoptotic damage to A-549 cell lines & [35] \\
\hline Anti-colon adenocarcinoma & Japan & Low molecular weight fucoidan fraction $(5-30 \mathrm{kDa})$ & Induce apoptotic damage to WiDr cell lines. & [35] \\
\hline Anti-breast cancer & Japan & $\begin{array}{l}\text { A partially acetylated galactofucan with a high } \\
\text { degree of sulfation and its main chain is built up of } \\
(1 \rightarrow 3) \text { - and/or }(1 \rightarrow 4) \text {-a-L-fucopyranose residues. }\end{array}$ & $\begin{array}{l}\text { Induce apoptosis in cancer cell lines as well as having } \\
\text { antimetastatic activity blocking the interactions } \\
\text { between cancer cells and the basement membrane. }\end{array}$ & [2] \\
\hline \multirow{2}{*}{ Anti-melanoma } & Japan & Same as the above. & Same as the above. & [2] \\
\hline & Korea & $\begin{array}{l}\text { Fucoidan with low molecular weights of } 89,35,17, \\
\text { and } 6 \mathrm{kDa} \text { (prepared by radiation-degradation of a } \\
378 \mathrm{kDa} \text { fucoidan) }\end{array}$ & $\begin{array}{l}\text { Fucoidan inhibits tyrosinase and increases radical } \\
\text { scavenging activity. }\end{array}$ & [26] \\
\hline Antioxidant & Korea & Fucoidan with high sulfate content & $\begin{array}{l}\text { Fucoidan directly scavenges the free radicals produced } \\
\text { inside the body, effectively abrogate oxidative stress. }\end{array}$ & [47] \\
\hline Anticoagulant & Italy & Sulfonated polysaccharides of fucoidan & $\begin{array}{l}\text { The sulfonated polysaccharides interfere with both the } \\
\text { extrinsic and intrinsic pathways of coagulation } \\
\text { inhibiting clot formation, that has an action similar to } \\
\text { that carried out by heparin. }\end{array}$ & [51] \\
\hline Antibacterial & Korea & Sulphated polysaccharides of fucoidan & $\begin{array}{l}\text { Inhibition of peptidoglycan formation, or the presence } \\
\text { of special cell wall components of Gram-negative } \\
\text { bacteria that act as a barrier for fucoidan. }\end{array}$ & [55] \\
\hline
\end{tabular}




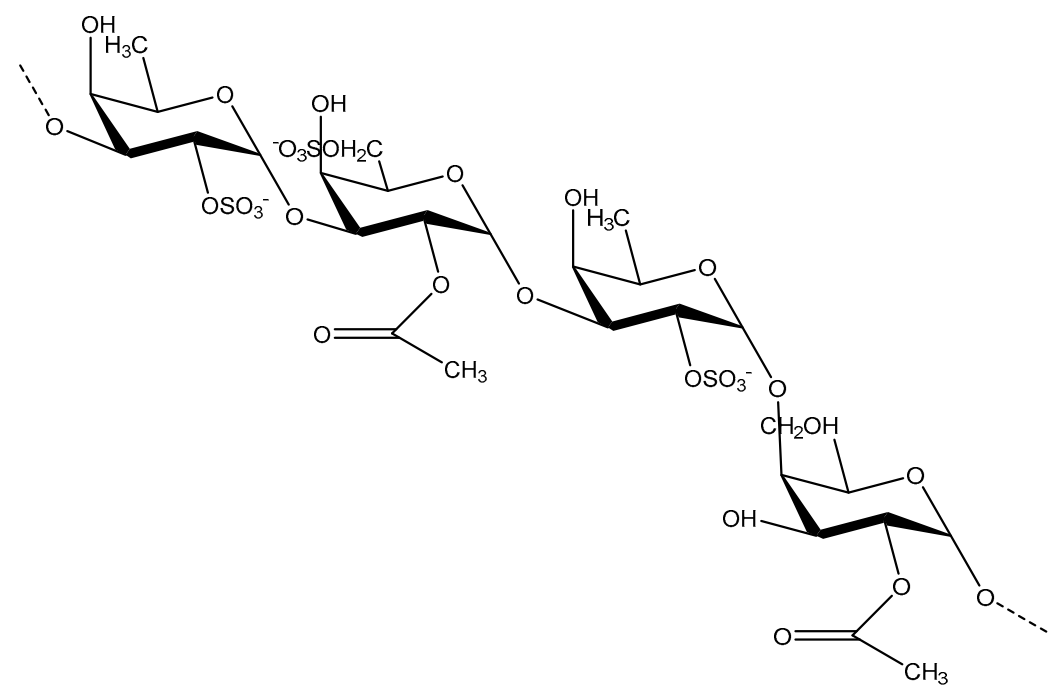

Figure 5. Basic structure of fucoidan from Undaria pinnatifida.

\section{Fucoidan as Functional Food and Therapeutic Agent}

Functional food is foods that have been demonstrated to provide specific health benefits beyond the basic nutrition. The design of functional foods is hence associated with the concept of preventing diseases and/or improving the health of consumers, besides the basic nutrient needs. Notably, fucoidans have been evidenced to play a vital role in human nutrition and health on the account of their biological activities and health benefits. Fucoidan from $U$. pinnatifida possesses great potential to be used as a functional food to reduce diseases or as a supplement for alternative therapy.

Quite a number of functional foods using $U$. pinnatifida containing fucoidan have been developed, and related patents have been registered. Table 4 lists some of those products (cookie, beverages, noodles, tea, and restructured meat) and their claimed benefits. Furthermore, fucoidan based therapies have been shown to have reached various beneficial therapeutic goals in arthritis, blood homeostasis, influenza, and malaria (Table 5). Apart from the above-mentioned therapeutic potentials, fucoidan is also able to mediate cell differentiation and exert anti-inflammatory activity [60].

In a recent randomized, double-blind, controlled clinical trial, low-molecular-weight fucoidan has been used as a supplement to chemotherapeutic agents in patients with metastatic colorectal cancer (mCRC). It has been shown that the disease control rate has been significantly improved with this supplement, in a median follow-up period of 11.5 months. It is noteworthy that this is the first clinical trial evaluating the efficacy of fucoidan fraction as a supplemental therapy in the management of patients with mCRC [61].

To classify fucoidan as a supplemental therapeutic agent requires the possible interaction between fucoidan and other therapeutic agents to be studied. A recent report shows the effect of co-administration of fucoidan, derived from U. pinnatifida, on the pharmacokinetics of two commonly used hormonal drugs, letrozole and tamoxifen, in patients with breast cancer. Results suggest that fucoidan in the studied form and dosage could be taken concomitantly with letrozole and tamoxifen without the risk of significant pharmacokinetic interactions [62]. 
Table 4. Several products formulated with the use of $U$. pinnatifida and/or extracts.

\begin{tabular}{|c|c|c|c|c|c|}
\hline Functional Food & Processes/Preparation & Related Parameters & Food Sensory Evaluation & Results & Ref. \\
\hline Cookie & $\begin{array}{l}\text { Raw materials were mixed with } \\
\text { water to form a dough piece with } \\
2 \mathrm{~mm} \text { thick, finally baked }\end{array}$ & Wakame powder $20 \%$ & Crisp taste, delicious flavor & $\begin{array}{l}\text { Have the effect of reducing weight and } \\
\text { blood glucose. }\end{array}$ & [63] \\
\hline Beverages & $\begin{array}{l}\text { Raw juice was obtained after } \\
\text { U. pinnatifida was fermented by } 8 \% \\
\text { inoculated yeast at } 30^{\circ} \mathrm{C} \text { for } 24 \mathrm{~h} \text {. }\end{array}$ & $50 \%$ raw wakame juice. & $\begin{array}{l}\text { Rich aroma of wakame and } \\
\text { fermentation, sweet and sour } \\
\text { taste, no smell and other odor. }\end{array}$ & $\begin{array}{c}\text { Lowering blood pressure, lipids, and } \\
\text { cholesterols, impeding platelet aggregation } \\
\text { and preventing arteriosclerosis. }\end{array}$ & [64] \\
\hline Noodles & $\begin{array}{l}\text { Wakame, wheat flour and wheat } \\
\text { gluten flour were used. }\end{array}$ & No details & $\begin{array}{l}\text { Yellow-green color, slight } \\
\text { fragrance of wakame. }\end{array}$ & $\begin{array}{l}\text { Suitable for patients with high blood } \\
\text { pressure, glucose and lipids }\end{array}$ & [65] \\
\hline \multicolumn{6}{|c|}{ CVDs-related parameters in foods using U. pinnatifida } \\
\hline Tea & $\begin{array}{l}\text { Wakame was dried with hot air, } \\
\text { crushed to pieces, boiled with } \\
\text { water, and filtrated. }\end{array}$ & $\begin{array}{l}\text { ACE inhibition } \mathrm{IC}_{50}: \\
26.4 \pm 1.05 \mathrm{mg} / \mathrm{mL}\end{array}$ & Green color & $\begin{array}{l}\text { Contains rich minerals and suppresses } \\
\text { hypertensive activity of angiotensin I. }\end{array}$ & [66] \\
\hline Restructured meat & $\begin{array}{c}\text { Dried wakame was homogenized } \\
\text { with raw meat. }\end{array}$ & U. pinnatifida at $5 \%$ & No details & $\begin{array}{l}\text { Moderately ameliorated lipid profile in } \\
\text { hypercholesterolemic rats. }\end{array}$ & [67] \\
\hline Gel/emulsion meat systems & No details & U. pinnatifida at $5.6 \%$ & No details & $\begin{array}{l}\text { Increase } n-3 \text { PUFA and antioxidant, } \\
\text { Decrease } n-6 / n-3 \text { PUFA ratio and sodium. }\end{array}$ & [68] \\
\hline
\end{tabular}

CVDs—cardiovascular diseases; ACE—angiotensin I converting enzyme; PUFA—polyunsaturated fatty acids.

Table 5. Fucoidan based therapies and related parameters.

\begin{tabular}{|c|c|c|c|c|}
\hline Therapeutic Items & Trial & Administration & Observation & Ref. \\
\hline Arthritis & Collagen-induced arthritis in mice & $\begin{array}{l}100 \mathrm{kDa} \text { and } 1 \mathrm{kDa} \text { fractions orally } \\
\text { administered daily } 300 \mathrm{mg} / \mathrm{kg} \text { for } 49 \text { days }\end{array}$ & $\begin{array}{c}1 \mathrm{kDa} \text { fraction effectively inhibited whereas } \\
100 \mathrm{kDa} \text { exacerbated disease }\end{array}$ & [69] \\
\hline Blood Homeostasis & Healthy human subjects & $\begin{array}{l}3 \mathrm{~g} \text { of } U \text {. pinnatifida fucoidan were ingested } \\
\text { daily for } 12 \text { days by healthy subjects }\end{array}$ & $\begin{array}{l}\text { A significant prolongation of global } \\
\text { clotting time was noted }\end{array}$ & [70] \\
\hline \multirow[t]{2}{*}{ Influenza } & In vivo & Orally delivered less than $1 \mathrm{mcg} / \mathrm{mL}$ & $\begin{array}{l}\text { A marked inhibitory effect on the recent } \\
\text { H1N1 Influenza A virus }\end{array}$ & [71] \\
\hline & Mouse model & $5 \mathrm{mg}$ per day orally delivered & Strongly inhibited Influenza A infection & [72] \\
\hline Malaria & Plasmodium berghei-infected mice & Orally delivered for 4 days & $\begin{array}{l}\text { A 37\% suppressive effect and a significant } \\
\text { delay in the deaths from anemia }\end{array}$ & [73] \\
\hline
\end{tabular}




\section{Conclusions}

Over the recent years, there have been visible developments in the fields of functional food, nutraceutical, cosmeceutical, and pharmaceutical. There is a growing demand from the public to get food products that provide health benefits instead of just basic nutrition. There is an increasing awareness among consumers about health-promoting foods worldwide. Therefore, many new functional food products have been developed and are being developed with natural ingredients that provide health benefits. As reviewed above, there are extensive scientific evidence that $U$. pinnatifida-derived fucoidan possesses various health benefits. This opens up the potential of developing products containing $U$. pinnatifida-derived fucoidan into functional foods, nutraceuticals, cosmeceuticals, and even drugs (Figure 6). However, it is important to study how to retain and/or improve the functional properties (bioactivities) of fucoidan in different industrial processes, for example, increasing low molecular weight fucoidan percentage and/or the degree of sulfation. Another important consideration is the consumer's acceptance of the sensory properties of the newly developed fucoidan-containing products. Furthermore, developing new and advanced processing technologies will ensure the exploitation of fucoidan's beneficial bioactivities from those newly developed products.

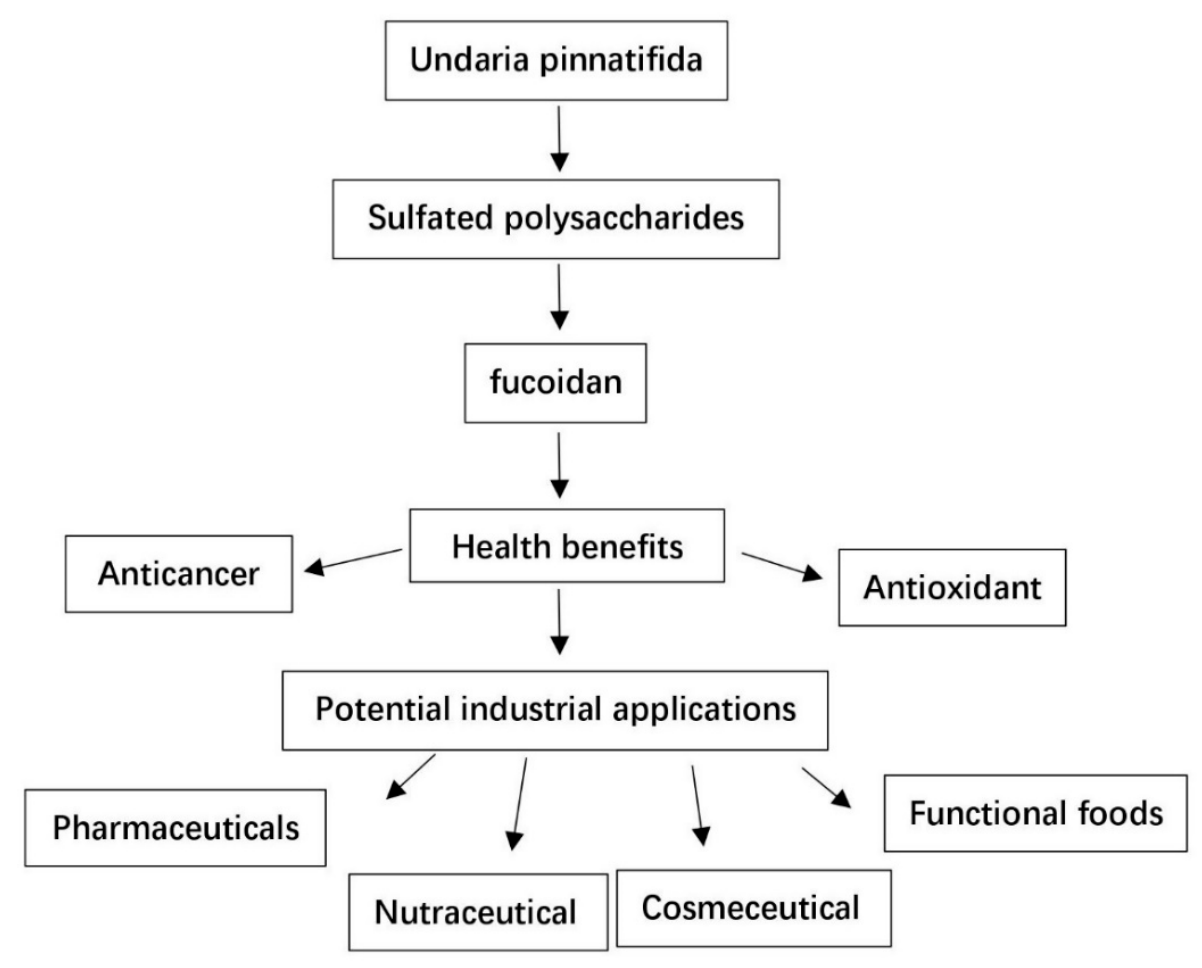

Figure 6. Biological properties and potential industrial uses of Undaria pinnatifida-derived fucoidan.

Author Contributions: Y.Z. (Yu Zhao) and J.L. conceived the idea, J.W., Y.Z. (Yizhou Zheng), S.M. and Y.Y. carried out the search, W.L.W., Y.Z. (Yu Zhao), Y.Z. (Yizhou Zheng), S.M., Y.Y., S.Y., F.Y. and J.L. analyzed the findings, S.M., J.W., Y.Z. (Yu Zhao), Y.Z. (Yizhou Zheng), Y.Y., W.L.W., and J.L. wrote the manuscript; all authors have read and agreed with the final submitted version.

Funding: This work was supported by the National Natural Science Foundation of China for Excellent Young Scholars (31422042); National Key Technology R \& D Program of China (2012BAD33B06); and the Performance-Based Research Fund of the Faculty of Health and Environmental Sciences, Auckland University of Technology.

Conflicts of Interest: The authors declare no conflicts of interest. 


\section{References}

1. Romano, G.; Costantini, M.; Sansone, C.; Lauritano, C.; Ruocco, N.; Ianora, A. Marine microorganisms as a promising and sustainable source of bioactive molecules. Mar. Environ. Res. 2017, 128, 58-69. [CrossRef] [PubMed]

2. Vishchuk, O.S.; Ermakova, S.P.; Zvyagintseva, T.N. Sulfated polysaccharides from brown seaweeds Saccharina japonica and Undaria pinnatifida: Isolation, structural characteristics, and antitumor activity. Carbohydr. Res. 2011, 346, 2769-2776. [CrossRef] [PubMed]

3. Kalimuthu, S.; Kim, S.K. Fucoidan, A Sulfated Polysaccharides from Brown Algae as Therapeutic Target for Cancer; Springer International Publishing: Cham, Switzerland, 2015; pp. 145-164, ISBN 978-3-319-07144-2.

4. Kylin, H. Biochemistry of sea algae. HZ Physiol. Chem. 1913, 83, 171-197. [CrossRef]

5. Hewitt, C.L.; Campbell, M.L.; Mcennulty, F.; Moore, K.M.; Murfet, N.B.; Robertson, B.; Schaffelke, B. Efficacy of physical removal of a marine pest: The introduced kelp Undaria pinnatifida in a Tasmanian Marine Reserve. Biol. Invasions 2005, 7, 251-263. [CrossRef]

6. Fletcher, R.L.; Farrell, P. Introduced brown algae in the North East Atlantic, with particular respect to Undaria pinnatifida (Harvey) suringar. Helgoländer Meeresuntersuchungen 1998, 52, 259-275. [CrossRef]

7. Wallentinus, I. Alien Species Alert: Undaria pinnatifida:(Wakame or Japanese Kelp); The Council: Göteborg, Sweden, 2007; ISBN 8774820559.

8. Helen, F.J. Method and composition for the treatment of a viral infection. Arch. Oral. Biol. 2006, 41, $299-305$.

9. Yang, C.; Chung, D.; Shina, I.; Lee, H.; Kim, J.; Lee, Y.; You, S. Effects of molecular weight and hydrolysis conditions on anticancer activity of fucoidans from sporophyll of Undaria pinnatifida. Int. J. Biol. Macromol. 2008, 43, 433-437. [CrossRef] [PubMed]

10. Stuart, M.D. Review of Research on Undaria pinnatifida in New Zealand and Its Potential Impacts on the Eastern Coast of the South Island; Department of Conservation: Wellington, New Zealand, 2004; ISBN 0-478-22090-1.

11. Nishino, T.; Nagumo, T. The sulfate-content dependence of the anticoagulant activity of a fucan sulfate from the brown seaweed Ecklonia kurome. Carbohydr. Res. 1991, 214, 193. [CrossRef]

12. Ale, M.T.; Mikkelsen, J.D.; Meyer, A.S. Important Determinants for Fucoidan Bioactivity: A Critical Review of Structure-Function Relations and Extraction Methods for Fucose-Containing Sulfated Polysaccharides from Brown Seaweeds. Mar. Drugs 2011, 9, 2106-2130. [CrossRef] [PubMed]

13. Hahn, T.; Lang, S.; Ulber, R.; Kai, M. Novel procedures for the extraction of fucoidan from brown algae. Process Biochem. 2012, 47, 1691-1698. [CrossRef]

14. Rani, V. Influence of Species, Geographic Location, Seasonal Variation and Extraction Method on the Fucoidan Yield of the Brown Seaweeds of Gulf of Mannar, India. Indian J. Pharm. Sci. 2017, 79, 65-71. [CrossRef]

15. Jia Yucui, Y.B.J.Y. Research on extracting technique of fucoidin from Undaria pinnatifuta. China Mod. Med. 2009, 16, 69.

16. Kim, W.J.; Kim, S.M.; Kim, H.G.; Oh, H.R.; Lee, K.B.; Lee, Y.K.; Park, Y.I. Purification and anticoagulant activity of a fucoidan from Korean Undaria pinnatifida sporophyll. J. Microbiol. Biotechnol. 2007, 21, 1043-1048. [CrossRef]

17. Rodriguez-Jasso, R.M.; Mussatto, S.I.; Pastrana, L.; Aguilar, C.N.; Teixeira, J.A. Microwave-assisted extraction of sulfated polysaccharides (fucoidan) from brown seaweed. Carbohydr. Polym. 2011, 86, 1137-1144. [CrossRef]

18. Song, K.M.; Su, J.H.; Lee, J.E.; Kim, S.H.; Yong, H.K.; Kim, Y.; Hong, S.P.; Jung, S.K.; Lee, N.H. High yield ultrasonication extraction method for Undaria pinnatifida sporophyll and its anti-inflammatory properties associated with AP-1 pathway suppression. LWT Food Sci. Technol. 2015, 64, 1315-1322. [CrossRef]

19. Wang, W.; Wang, G.; Fang, H. Study on Extraction of sulfated polysaccharides from Chinese Cabbage by complex enzymatic hydrolysis. Food Sci. 1999, 20, 26-29.

20. Waffenschmidt, S.; Jaenicke, L. Assay of reducing sugars in the nanomole range with 2,2'-bicinchoninate. Anal. Biochem. 1987, 165, 337-340. [CrossRef]

21. Skriptsova, A.V.; Shevchenko, N.M.; Zvyagintseva, T.N.; Imbs, T.I. Monthly changes in the content and monosaccharide composition of fucoidan from Undaria pinnatifida (Laminariales, Phaeophyta). J. Appl. Phycol. 2010, 22, 79-86. [CrossRef] 
22. Lee, J.B.; Hayashi, K.; Hashimoto, M.; Nakano, T.; Hayashi, T. Novel antiviral fucoidan from sporophyll of Undaria pinnatifida (Mekabu). Chem. Pharm. Bull. 2004, 52, 1091-1094. [CrossRef] [PubMed]

23. Hemmingson, J.A.; Falshaw, R.; Furneaux, R.H.; Thompson, K. Structure and antiviral activity of the galactofucan sulfates extracted from Undaria pinnatifida (Phaeophyta). J. Appl. Phycol. 2006, 18, 185-193. [CrossRef]

24. Sakai, T.; Ishizuka, K.; Shimanaka, K.; Ikai, K.; Kato, I. Structures of Oligosaccharides Derived from Cladosiphon okamuranus Fucoidan by Digestion with Marine Bacterial Enzymes. Mar. Biotechnol. 2003, 5, 536-544. [PubMed]

25. Koo, J.G.; Jo, K.S.; Do, J.R.; Woo, S.J. Isolation and purification of fucoidans from Laminaria religiosa and Undaria pinnatifida in Korea. Korean J. Fish. Aquat. Sci. 1995, 28, 227-236.

26. Park, E.J.; Choi, J.I. Melanogenesis inhibitory effect of low molecular weight fucoidan from Undaria pinnatifida. J. Appl. Phycol. 2017, 29, 2213-2217. [CrossRef]

27. Qiu, X.; Amarasekara, A.; Doctor, V. Effect of oversulfation on the chemical and biological properties of fucoidan. Carbohydr. Polym. 2006, 63, 224-228. [CrossRef]

28. Synytsya, A.; WooJung, K.; SungMin, K.; Pohl, R.; Synytsya, A.; Kvasnička, F.; Čopíková, J.; YongIl, P. Structure and antitumour activity of fucoidan isolated from sporophyll of Korean brown seaweed Undaria pinnatifida. Carbohydr. Polym. 2010, 81, 41-48. [CrossRef]

29. Sekkal, M.; Legrand, P. A spectroscopic investigation of the carrageenans and agar in the $1500-100 \mathrm{~cm}^{-1}$ spectral range. Spectrochim. Acta A Mol. Spectr. 1993, 49, 209-221. [CrossRef]

30. Yuan, M.X.; Fei, W.Y.; Yanmei, Z.; Yanyan, K.; Iiang, Z. PoJysaccharjdes from Undaria pinnatifida. Chin. Tradit. Herbal Drug 2006, 37, 362-365.

31. Mak, W.; Wang, S.K.; Liu, T.; Hamid, N.; Li, Y.; Lu, J.; White, W.L. Anti-Proliferation Potential and Content of Fucoidan Extracted from Sporophyll of New Zealand Undaria pinnatifida. Front. Nutr. 2014, 1, 9. [CrossRef] [PubMed]

32. Honya, M.; Mori, H.; Anzai, M.; Araki, Y.; Nisizawa, K. Monthly changes in the content of fucans, their constituent sugars and sulphate in cultured Laminaria japonica. Hydrobiologia 1999, 398-399, 411-416. [CrossRef]

33. Fletcher, H.R.; Biller, P.; Ross, A.B.; Adams, J.M.M. The seasonal variation of fucoidan within three species of brown macroalgae. Algal. Res. 2017, 22, 79-86. [CrossRef]

34. Thakur, V.; Lu, J.; Roscilli, G.; Aurisicchio, L.; Cappelletti, M.; Pavoni, E.; White, W.L.; Bedogni, B. The natural compound fucoidan from New Zealand Undaria pinnatifida synergizes with the ERBB inhibitor lapatinib enhancing melanoma growth inhibition. Oncotarget 2017, 8, 17887-17899. [CrossRef] [PubMed]

35. Wang, S.; Li, Y.; White, W.; Lu, J. Extracts from New Zealand Undaria pinnatifida Containing Fucoxanthin as Potential Functional Biomaterials against Cancer in Vitro. J. Funct. Biomater. 2014, 5, 29-42. [CrossRef] [PubMed]

36. Che, J.; Li, W.; Yan, Y.; Liu, M.; Wang, G.; Li, Q.; Yang, B.; Yao, X.; Zheng, J. Expression and clinical significance of the nin one binding protein and p38 MAPK in prostate carcinoma. Int. J. Clin. Exp. Pathol. 2013, 6, 2300-2311. [PubMed]

37. Yang, L.; Wang, P.; Wang, H.; Li, Q.; Teng, H.; Liu, Z.; Yang, W.; Hou, L.; Zou, X. Fucoidan Derived from Undaria pinnatifida Induces Apoptosis in Human Hepatocellular Carcinoma SMMC-7721 Cells via the ROS-Mediated Mitochondrial Pathway. Mar. Drugs 2013, 11, 1961-1976. [CrossRef] [PubMed]

38. Mak, W.; Hamid, N.; Liu, T.; Lu, J.; White, W.L. Fucoidan from New Zealand Undaria pinnatifida: Monthly variations and determination of antioxidant activities. Carbohydr. Polym. 2013, 95, 606-614. [CrossRef] [PubMed]

39. Lahrsen, E.; Liewert, I.; Alban, S. Gradual degradation of fucoidan from Fucus vesiculosus and its effect on structure, antioxidant and antiproliferative activities. Carbohydr. Polym. 2018, 192, 208-216. [CrossRef] [PubMed]

40. Haroun-Bouhedja, F.; Ellouali, M.; Sinquin, C.; Boisson-Vidal, C. Relationship between Sulfate Groups and Biological Activities of Fucans. Thromb. Res. 2000, 100, 453. [CrossRef]

41. Zhao, X.; Xue, C.; Cai, Y.; Wang, D.; Fang, Y.U. The study of antioxidant activities of fucoidan from Laminaria japonica. High Technol. Lett. 2005, 11, 91-94.

42. Koyanagi, S.; Tanigawa, N.; Nakagawa, H.; Soeda, S.; Shimeno, H. Oversulfation of fucoidan enhances its anti-angiogenic and antitumor activities. Biochem. Pharmacol. 2003, 65, 173-179. [CrossRef] 
43. Seng, J.L.; Wan, M.W.A.; Maskat, M.Y.; Mamot, S.; Ropien, J.; Mohd, D.M. Isolation and antioxidant capacity of fucoidan from selected Malaysian seaweeds. Food Hydrocoll. 2014, 42, 280-288.

44. Wang, J.; Zhang, Q.; Zhang, Z.; Song, H.; Li, P. Potential antioxidant and anticoagulant capacity of low molecular weight fucoidan fractions extracted from Laminaria japonica. Int. J. Biol. Macromol. 2010, 46, 6-12. [CrossRef] [PubMed]

45. Kahl, R.; Kappus, H. Toxicology of the synthetic antioxidants BHA and BHT in comparison with the natural antioxidant vitamin E. Zeitschrift fur Lebensmittel-Untersuchung und Forschung 1993, 196, 329. [CrossRef] [PubMed]

46. Wang, J.; Zhang, Q.; Zhang, Z.; Li, Z. Antioxidant activity of sulfated polysaccharide fractions extracted from Laminaria japonica. Int. J. Biol. Macromol. 2008, 42, 127-132. [CrossRef] [PubMed]

47. Phull, A.R.; Majid, M.; Haq, I.U.; Khan, M.R.; Kim, S.J. In vitro and in vivo evaluation of anti-arthritic, antioxidant efficacy of fucoidan from Undaria pinnatifida (Harvey) Suringar. Int. J. Biol. Macromol. 2017, 97, 468-480. [CrossRef] [PubMed]

48. Ustyuzhanina, N.; Ushakova, N.; Zyuzina, K.; Bilan, M.; Elizarova, A.; Somonova, O.; Madzhuga, A.; Krylov, V.; Preobrazhenskaya, M.; Usov, A.; et al. Influence of Fucoidans on Hemostatic System. Mar. Drugs 2013, 11, 2444-2458. [CrossRef] [PubMed]

49. Nishino, T.; Nagumo, T.; Kiyohara, H.; Yamada, H. Structural characterization of a new anticoagulant fucan sulfate from the brown seaweed Ecklonia kurome. Carbohydr. Res. 1991, 211, 77-90. [CrossRef]

50. Zayed, A.; Hahn, T.; Rupp, S.; Krämer, R.; Ulber, R. Fucoidan as a natural anticoagulant, antiviral and anti-cancer drug. German Pharm-Tox Summit 2018, 391, S7-S8.

51. Faggio, C.; Pagano, M.; Morabito, M.; Minicante, S.A.; Arfuso, F.; Genovese, G. In vitro assessment of the effect of Undaria pinnatifida extracts on erythrocytes membrane integrity and blood coagulation parameters of Equus caballus. Coast Life Med. J. 2014, 16, e249.

52. Casella, S.; Giannetto, C.; Giudice, E.; Marafioti, S.; Fazio, F.; Assenza, A.; Piccione, G. ADP-induced platelet aggregation after addition of tramadol in vitro in fed and fasted horses plasma. Res. Vet. Sci. 2013, 94, 325-330. [CrossRef] [PubMed]

53. Favaloro, E.J.; Lippi, G.; Koutts, J. Laboratory testing of anticoagulants: The present and the future. Pathology 2011, 43, 682-692. [CrossRef] [PubMed]

54. Mourão, P.A.; Pereira, M.S. Searching for alternatives to heparin: Sulfated fucans from marine invertebrates. Trends Cardiovasc. Med. 1999, 9, 225. [CrossRef]

55. Ibtissam, C.; Hassane, R.; Martinezlopez, J.; Seglar, J.F.D.; Vidal, J.A.G.; Hassan, B.; Mohamed, K. Screening of antibacterial activity in marine green and brown macroalgae from the coast of Morocco. Afr. J. Biotechnol. 2009, 8, 1258-1262.

56. Nagayama, K.; Iwamura, Y.; Shibata, T.; Hirayama, I.; Nakamura, T. Bactericidal activity of phlorotannins from the brown alga Ecklonia kurome. J. Antimicrob. Chemother. 2002, 50, 889-893. [CrossRef] [PubMed]

57. Jiao, G.; Yu, G.; Zhang, J.; Ewart, H. Chemical Structures and Bioactivities of Sulfated Polysaccharides from Marine Algae. Mar. Drugs 2011, 9, 196-223. [CrossRef] [PubMed]

58. Fitton, J.H. Therapies from Fucoidan; Multifunctional Marine Polymers. Mar. Drugs 2011, 9, 1731-1760. [CrossRef] [PubMed]

59. Pomin, V.H. Fucanomics and galactanomics: Current status in drug discovery, mechanisms of action and role of the well-defined structures. Biochim. Biophys. Acta 2012, 1820, 1971-1979. [CrossRef] [PubMed]

60. Phull, A.R.; Song, J.K. Fucoidan from Undaria pinnatifida regulates type II collagen and COX-2 expression via MAPK and PI3K pathways in rabbit articular chondrocytes. Biologia 2017, 72, 1362-1369. [CrossRef]

61. Tsai, H.; Tai, C.; Huang, C.; Chang, F.; Wang, J. Efficacy of Low-Molecular-Weight Fucoidan as a Supplemental Therapy in Metastatic Colorectal Cancer Patients: A Double-Blind Randomized Controlled Trial. Mar. Drugs 2017, 15, 122. [CrossRef] [PubMed]

62. Tocaciu, S.; Oliver, L.J.; Lowenthal, R.M.; Peterson, G.M.; Patel, R.; Shastri, M.; Mcguinness, G.; Olesen, I.; Fitton, J.H. The Effect of Undaria pinnatifida Fucoidan on the Pharmacokinetics of Letrozole and Tamoxifen in Patients with Breast Cancer. Integr. Cancer Ther. 2018, 17, 99-105. [CrossRef] [PubMed]

63. Zhou, X. Research and Development of Two Kinds of Functional Food. Ph.D. Dissertation, Ocean University of China, Beijing, China, 2011.

64. Kong, F.D.; Xu, B.; Zu, G.R.; Sun, H.; Liu, Z.F. Study on the processing technology of the fermented beverage of the Chinese Cabbage. China Brew. 2011, 1, 186-189. 
65. Dong, S.; Hou, W.; Dong, J.; Duan, Z.; Zhao, J.; Dong, X. A Kind of Spaghetti and Its Production Method. Chinese Patent No. CN 104509780A, 15 April 2015.

66. Nagai, T.; Suzuki, N.; Nagashima, T. Angiotensin I-converting enzyme inhibitory activities of beverages made from sea algae and commercially available tea extracts. J. Food Agric. Environ. 2006, 4, 35-48.

67. Olivero-David, R.; Schultz-Moreira, A.; Vã, Z.M.; Gonzã, L.L.; Bastida, S.; Benedã, J.; Sanchez-Reus, M.I.; González-Muñoz, M.J.; Sánchez-Muniz, F.J. Effects of Nori- and Wakame-enriched meats with or without supplementary cholesterol on arylesterase activity, lipaemia and lipoproteinaemia in growing Wistar rats. Br. J. Nutr. 2011, 106, 1476-1486. [CrossRef] [PubMed]

68. Lã Pez-Lã Pez, I.; Bastida, S.; Ruiz-Capillas, C.; Bravo, L.; Larrea, M.T.; Sã, N.F.; Cofrades, S.; Nez-Colmenero, F.J. Composition and antioxidant capacity of low-salt meat emulsion model systems containing edible seaweeds. Meat. Sci. 2009, 83, 492-498. [CrossRef] [PubMed]

69. Park, S.B.; Chun, K.R.; Kim, J.K.; Suk, K.; Jung, Y.M.; Lee, W.H. The differential effect of high and low molecular weight fucoidans on the severity of collagen-induced arthritis in mice. Phytother. Res. 2010, 24, 1384-1391. [CrossRef] [PubMed]

70. Irhimeh, M.R.; Fitton, J.H.; Lowenthal, R.M. Pilot clinical study to evaluate the anticoagulant activity of fucoidan. Blood Coagul. Fibrinol. 2009, 20, 607. [CrossRef] [PubMed]

71. Hayashi, T.; Hayashi, K.; Kanekiyo, K.; Ohta, Y.; Jungbum, L.; Hashimoto, M.; Nakano, T.; Torrence, P.F. Promising Antiviral Glyco-Molecules from an Edible Alga; John Wiley \& Sons, Inc.: Hoboken, NJ, USA, 2007; pp. 166-182, ISBN 978-470-11879-5.

72. Chen, J.H.; Lim, J.D.; Sohn, E.H.; Choi, Y.S.; Han, E.T. Growth-inhibitory effect of a fucoidan from brown seaweed Undaria pinnatifida on Plasmodium parasites. Parasitol. Res. 2009, 104, 245-250. [CrossRef] [PubMed]

73. Kumar, M.; Kumari, P.; Trivedi, N.; Shukla, M.K.; Gupta, V.; Reddy, C.R.K.; Jha, B. Minerals, PUFAs and antioxidant properties of some tropical seaweeds from Saurashtra coast of India. J. Appl. Phycol. 2011, 23, 797-810. [CrossRef]

(C) 2018 by the authors. Licensee MDPI, Basel, Switzerland. This article is an open access article distributed under the terms and conditions of the Creative Commons Attribution (CC BY) license (http:/ / creativecommons.org/licenses/by/4.0/). 